\title{
EFFECT OF SOME NATURAL AND SYNTHETIC COMPOUNDS ON THE PROTEIN PATTERN OF MUscina stabulans (FALLEN) PUPAE. \\ Shoukry, I.F.a; A. A. Khalaf ${ }^{a}$; K.T.Hussein ${ }^{a}$ and A. H.Ismail ${ }^{b}$ \\ a; Department of Zoology, Faculty of Science, Zagazig University, Zagazig, Egypt. \\ b; Department of Chemistry, Faculty of Science, Mansoura University, Mansoura, Egypt.
}

\section{ABSTRACT}

The present investigation deals with the effect of Insect growth regulator (Flufenoxuron), volatile oil extract of Imperata cylinderica and fixed oil extract of Glycine soja on the protein pattern of Muscina stabulans pupae resulting from treated third larval instar. The mean total protein content was disturbed by the $\mathrm{LC}_{50}$ of the tested compounds. These results were verified electrophoretically as the tested compounds caused disturbance in the protein fractions through the appearance and disappearance of some protein bands compared with that of control.

\section{INTRODUCTION}

Several studies in different parts of the world show that non-biting flies (like our fly under study, Muscina stabulans) carry different stages of helminth and protozoan parasites. For example, Sulaiman et al. (1988), isolated eggs of Ascaris lumbricoides, Trichuris trichiura and hookworms from fly species of Chrysomya, Sarcophaga and Musca, which were collected from refuse dump and peridomestic sites in Malaysia. Non-biting flies are often associated with domestic dwellings, human and animal excreta and other wastes, especially during the dry season when they breed prolifically and cause a constant annoyance for humans. The free interchange that flies have with such sites ensures that they are laden with disease causing organisms on their mouthparts, body hairs and sticky pads of their feet, as well as in their stomachs, faeces and vomitus (Graczyk et al., 2005). The use of environmentally friendly and biodegradable natural insecticides of plant origin has received renewed attention as agents for disease vector control such as microbial sprays, and insect growth regulators admist other control measures such as beneficial insects and all, necessitate an integration of supervised control (Ascher et al., 1995; Senthil et al., 2004, 2005). Owing to the medical importance of Muscina stabulans, the present work was undertaken to investigate the effects of some plant extracts and insect growth regulators against this fly.

\section{MATERIALS AND METHODS}

1. Insect culture:

Muscina stabulans adults were collected from Dakahlia provience. They were reared in the laboratory for five successive generations before being used in experiments, according to the method described by ElShazly et al. (1996). 
2-Tested compounds:

i- Volatile oil extract of Imperata cylinderica

Steam distillation technique was used for extraction of this oil according to the methods of Anderson et al. (1980).

ii- Fixed oil extract of Glycine soja

Extraction of the fixed oil was performed from crushed and previously steam distilled plant parts. Where the dry powdered plants were macerated in petroleum-ether (40-60) according to Harborne (1984) and El-Sayed et al. (1989).

iii- IGR (Flufenoxuron).

2. Biochemical studies:

Third instar larvae were dipped for five seconds in (LC50s) petroleum ether (40-60) solution of Imperata cylinderica volatile oil, Glycine soja fixed oil and flufenoxuron at a concentration of $0.139,0.19$ and 0.0052 percentage respectively as reported by Khalaf and Hussein (1997). The total proteins and the protein fraction SDS-Page were determined in the fresh whole body homogenate.

A. Determination of total proteins:

The total proteins were determined according to Lowery et al. (1951).

B. Separation of protein bands by electrophoresis:

Haemolymph proteins of the pupae came from control and treated 3rd instar larvae of Muscina stabulans were electrophoretically separated using SDS-page according to (Davis, 1964).

\section{RESULTS AND DISCUSSION}

Treatment of third instar larvae of Muscina stabulans with (LC50) of Imperata cylinderica volatile oil, Glycine soja fixed oil and flufenoxuron induced a disturbance in the total protein content of the resulting pupae.

A. Determination of total proteins:

The insect proteins are numerous; among them are storage protein, vitellogenin, lipophrin and a large amount of other major proteins with unknown fractions Kyung and Kim (1990).

Data in table (1) and figs. (1,2\&3) illustrate that the LC 50 s of IGR (Flufenoxuron) caused significant reduction in mean total protein content at two and four days old pupae, while it gave no significant effect at six days old pupae in comparison with that of control. LC 50 of fixed oil of Glycine soja significantly decreased the determined criterion only at four days old pupae compared with control groups.

Table (1): Effect of the tested compounds on the total proteins of $M$. stabulans pupae treated as $3^{\text {rd }}$ larval instar $(\mathrm{mg} / \mathrm{g}$ fresh body weight):

\begin{tabular}{|c|c|c|c|}
\hline \multirow{2}{*}{ Treatment } & \multicolumn{3}{|c|}{ Age of pupae per days } \\
\cline { 2 - 4 } & $\mathbf{2}$ & $\mathbf{4}$ & $\mathbf{6}$ \\
\hline IGR's (Flufenoxuron) & $15.86 \pm 0.012^{*}$ & $23.15 \pm 0.019^{*}$ & $25.1 \pm 0.016$ \\
\hline $\begin{array}{c}\text { Volatile oil of } \\
\text { Imperata cylinderica }\end{array}$ & $24.94 \pm 0.021^{*}$ & $26.68 \pm 0.013^{*}$ & $25.91 \pm 0.021$ \\
\hline Fixed oil of Glycine soja & $19.98 \pm 0.017$ & $28.8 \pm 0.015^{*}$ & $27.22 \pm 0.023$ \\
\hline Control & $20.13 \pm 0.016$ & $36.36 \pm 0.018$ & $23.7 \pm 0.016$ \\
\hline \multicolumn{4}{|c}{$\mathbf{2}$}
\end{tabular}


J. Agric. Sci. Mansoura Univ., 34 (10), October, 2009

Fig1,2,3 
Volatile oil of Imperata cylinderica significantly increased the mean total protein content at two days old pupae, followed by significant decrease at four days old pupae then recovered (insignificant effect) nearly as in control at six days old pupae.

Similar results were arrived by Abdel-Hafez et al. (1988) where the IGR's diflubenzuron and triflumuron caused a reduction in the levels of proteins and free amino acids of the treated $S$. littoralis larvae. Ismail and Fouad (1985) found that juvenile hormone analogue (Isopropyl, 3, 7, 11trimethyl, 2, 4, Dodencadienoate) induced an increase in the total protein content all over the pupal period of Chrysomia albiceps.

High doses of azadirachtin caused metabolic defects and the stored proteins in the fat bodies, which are necessary for pupation, did not occur in last larval instar of Epilachna varivestis (Schloter, 1985). El-Sheakh et al. (1990) noticed an increase in total soluble protein in the 4th instar larvae of $S$. littoratis treated with Soybean phytoalexins (plant extract). Abou El-Ela et al. (1995) reported a significant decrease in the total protein content in the house fly M. demostica larvae treated with plant extracts. Khalaf (1998) showed that the volatile oils of $C$. citratus and $R$. officinalis induced biochemical disturbance in the pupae of $M$. stabulans, which originated from treated larvae by decreasing the protein content. Shoukry and Hussein (1998) reported similar results on the greater wax moth Galleria mellonella.

Shoukry et al. (2003) showed that haemolymph proteins content of Plodia interpunctella larvae was significantly increased in all treatments by fixed and volatile oils. Sabry (2004) reported significantly decreased in total protein content of Chrysomyia albiceps larvae with treatment by fixed and volatile oils. Fell et al. (1982), Rajender (1990) and Shakoori and Saleem (1991) attributed the greater protein synthesis with insecticidal treatment, to the synthesis of the proteinase needed for insecticide detoxification. This may be due to the conversion of carbohydrates and lipids to proteins as stated by Kinnear et al. (1971) who suggested that increased of protein level due to increased synthesis of new proteins by fat body, haemolymph and other tissues of the larvae. Thus, the increase in the total protein may be a kind of detoxification mechanism. In this respect, Wilkinson (1976) stated that protein helps to synthesize microsomal detoxifying enzyme, which assists to detoxify the toxicants that entered into the body.

Chitin synthesis inhibitors act by interrupting the synthesis and transport of specific proteins that are required for the assembly of N-acetyl-Dglucosamine (Glc-NAC) monomers into polymeric chitin (Oberlander et al., 1998). It is also a well-established fact that living organisms respond at the cellular level to unfavorable conditions such as heat or other stressful situations including exposure to xenobiotics, UV, heavy metals, oxidizing agents, mutagens, carcinogens, insecticides, and gene expression inhibitors, by expression of specific sets of proteins called the heat shock/stress proteins (Linquist, 1986; Nover, 1991; Feeder, 1996 and Delinger and Yocum, 1998). Recent studies indicate that stress proteins play a role in toxicity since they are induced as a result of damages caused to the cell by the toxicant (Hightower, 1991 and Sanders, 1993). 


\section{B. Separation of protein bands by electrophoresis:}

Haemolymph proteins of the pupae came from control and treated $3^{\text {rd }}$ instar larvae of Muscina stabulans were electrophoretically separated using SDS-page. The separating gel was 10\% acrylamide.

Plates (I\&II) show the electrophoretic patterns (electrophoregrams) obtained for haemolymph proteins from the control pupae with $\mathrm{LC}_{50}$ of Imperata cylinderica, Glycine soja and the IGR (Flufenoxuron) respectively. At the same time protein M.Wt. standard were separated to be used as a reference for the molecular weights of the separated protein bands.

\section{1-) Two days old pupae:}

A total number of forty six different protein bands with molecular weights ranging from 3-91.8 k.dalton, were distinguished. Sixteen protein fractions were separated from haemolymph proteins of the control pupae (fig. 4). Eighteen, seventeen and fourteen bands were separated from the Imperata cylinderica volatile oil, Glycine soja fixed oil and the IGR (Flufenoxuron) (figs. 5, 6 and 7), respectively. Among these five fractions (no. $9,10,20,22$ and 38) were always permanent or dominant in both treated and untreated pupae with M.Wts. equal, 71.9, 67.4, 57.9 and 3.1 K.Da, respectively. However their relative percentages and intensities fluctuated, they are stage specific proteins. The other protein fractions ( 41 fractions) are often related to the type of applicable materials and therefore they are considered as treatment dependent.

\section{2- ) Four days old pupae:}

A total number of thirty six different protein bands with molecular weights ranging from $3.16-72.17$ k.dalton, were distinguished. Thirteen protein fractions were separated from haemolymph proteins of the control pupae (fig. 8).Ten; thirteen and twelve bands were separated from the Imperata cylinderica volatile oil, Glycine soja fixed oil and the IGR (Flufenoxuron) (figs. 9, 10 and 11), respectively. Among these three fractions ( no.4,5 and 17) were always permanent or dominant in both treated and untreated pupae with M.Wts. equal, $67.4,66.95$ and 57.9 K.Da, respectively. However their relative percentages and intensities fluctuated, they are stage specific proteins. The other protein fractions (33 fractions) are often related to the type of applicable materials and therefore they are considered as treatment dependent.

\section{3- ) Six days old pupae:}

A total number of forty four different protein bands with molecular weights ranging from 1.7- 91.58 k.dalton, were distinguished. Fourteen protein fractions were separated from haemolymph proteins of the control pupae (fig. 12). Eleven, sixteen and thirteen bands were separated from the Imperata cylinderica volatile oil, Glycine soja fixed oil and the IGR (Flufenoxuron) (figs. 13, 14 and 15), respectively. Among these three fractions (no.6, 8 and 19) were always permanent or dominant in both treated and untreated pupae with M.Wts. equal, 67.4, 66.94 and 57.9 K.Da, respectively. 
Shoukry, I.F. et al.

Plate1-11 
J. Agric. Sci. Mansoura Univ., 34 (10), October, 2009 Fig4,5,6 
Shoukry, I.F. et al.

Fig7,8,9

8 
J. Agric. Sci. Mansoura Univ., 34 (10), October, 2009

Fig10,11,12 
Shoukry, I.F. et al.

Fig13,14,15 
However their relative percentages and intensities fluctuated, they are stage specific proteins. The other protein fractions (41 fractions) are often related to the type of applicable materials and therefore they are considered as treatment dependent.

From the above mentioned data we can deduce that, treatment with plant fixed oil, volatile oil and IGR make disturbance in the protein fractions of treated pupae.

The appearance of new bands may be due to liberation of free radicals which affect directly the nitrogenous compounds this in turn lead to break down of the peptide linkage causing fragmentation of protein molecules. Also, the formation of extra-molecular size of one or more molecules is expected as the suggestion of Megahed (1996), and Gehad and Shaurub (1997). Another possible source of haemolymph free protein is the haemocytes which play a part in the metabolic process as growth and moulting (Wigglesworth, 1959).

Generally insects exihibit both cellular (haemocytes) and non cellular (humoral) defense mechanisms (Gotz and Boman, 1985; Brehelin, 1986 and Dunn, 1986). Recent studies on insect haemolymph indicated the presence of a variety of immune protein or molecules formed in response to the oil treatments. Such molecules act as agglutinins, lysis, precipitin, opsonin and microbicides (Fries, 1984 and Ratcliffe, 1985).In conclusion, the protein bands of treated samples were completely different from those of control, so it may be a difference in biological and biochemical activities as recorded by Mostafa et al. (1995). El-Beramawy and Abdel Fattah (2000) recorded that, it is worthy to note that the protein type has specific biological role according to this role the DNA secretes enzymes which act as catalyst to produce specific type of protein, this protein is responsible for specific biological process, due to the difference in protein bands between treated samples and control, the biological process may be different too. During stress conditions, animals need more energy to detoxify the toxicants to overcome stress (Tiwari and Singh 2003). At the chronic period of stress, the proteins were synthesized as a source of energy. If the carbohydrates are limited, the next alternative source of energy is protein to meet the increased energy demand. Perhaps, total protein level can also be low during some developmental stages of Muscina stabulans because of the reason mentioned above. On the other hand, the toxic effect of the tested compounds may have severe implications for the permeability of membranes. This leads to the release of some proteases, enzymes that degrade protein molecules, this in agreement with the findings of Agar et al. 2005.

\section{REFERENCES}

Abdel-Hafez, M.M.; Shaaban, M.N.; El-Malla, M.A.; Farag, M. and Abdel-Kawy, A.M. (1988): Effect of insect growth regulators on the activity of trans aminase with reference to protein and amino acids in the Egyptian cotton leafworm, S. littoralis (Boisd.). Minia. J. Agric. Res. \& Dev., 10: 1357-1372. 
Abou El-Ela, R.G.; Helmy, N.M.; El-Monairy, O.M. and Salah, H. (1995): Effect of certain plant extracts on some biochemical aspects of the house fly larvae Musca domestica (Diptera-Muscidae). Bull. Ent. Soc. Egypt. Econ. Ser, 22: 17-25.

Agar, G.; Uysal, H. and Kaya, Y. (2005): Toxic effects of aqueous extract of Nerium oleander (Apocynaceae) leaves and its latex on total protein level in fruit fly Drosophila melanogaster (Diptera: Drosophilidae).

Anderson, B.A.; Holman, R.T.; Lundgren, L. and Stenhagen, G. (1980): Capillary gas chromatogrpahy of leaf volatiles. A possible aid to breeders for pest and disease resistance. J. Agri. Food Chem., 28: 985-989.

Ascher, K.R.S.; Schmutterer, H.; Zebitz, C.P.W. and Naqvi, S.N.H. (1995): The Persian lilac or Chinaberry tree: Melia azedarach L. In: Schmutterer, $\mathrm{H}$. (Ed.), The Neem Tree: Source of Unique Natural Products for Integrated Pest Management, Medicine, Industry and Other Purposes. $\mathrm{VCH}$, Weinheim, Germany, pp. 605-642.

Brehelin, M. (1986): Immunity in invertebrates, 1st ed. Springer, Berlin.

Davis, B.J. (1964): Disc electrophoresis. II. Methods and application to human serum protein. Ann. N.Y. Acad. Sci., 21: 404-427.

Delinger, D.L. and Yocum, G.D. (1998): Physiology of heat sensitivity, in: G.J. Hallman, D.L. Delinger (Eds.), Temperature sensitivity in insects and application in Integrated Pest Management, Westviews Press, Oxford, pp. 7-53.

Dunn, P.E. (1986): Biochemical aspects of insect immunology. Ann. Rev. Entomol., 31: 321-339.

El Bermawy, S.M. and Abdel Fattah, H.M. (2000): Changes in protein electrophoretic pattern of Tribolium confusum 4th instar larvae after treatment with volatile plant oil (Vetiver). J. Egypt.Ger. Zool., 31:167-182.

El Sayed, F.M.A.; Etman, A.A. and Abdel-Razik, M. (1989): Effectiveness of natural oils in protecting some stored products from two stored product pests. Bull. Fac. Of Agric., Univ. of Cairo, 40(2):409-418.

El Shazly, M. M.; Nassar, M.I. and El Sherief, H. A. (1996): Toxic effect of ethanolic extract of Nerium oleander (Apocynaceae) leaves against different developmental stages of Muscina stabulans (Diptera-Muscidae). J-Egypt-Soc-Parasitol.; 26(2): 461-473.

El Sheakh, A.A.; Allam, S.M. and Mohamed, Z.I. (1990): Biological and biochemical changes occurring in $S$. littoralis larvae treated with Osbic, Cyanox and Soybean Phytoalexins. Egypt. J. Appl. Sci., 5(4): 292-302.

Feeder, M.E. (1996): Ecological and evolutionary physiology of stress proteins and the stress response: the Drosophila melanogaster model, in: I.A. Johnston (Ed.), Animals and Temperature: Phenotypic and Evolutionary Adaptation, Cambridge University Press, Cambridge, pp. 79-102.

Fell, D.; loneda, T.; Chiba, S. and Ginnott, O. (1982):Effect of disulfoton (Disyston) on the protein and carbohydrate content of the nervous system of cockroach, Periplaneta americana L. Arquivos do instituto Biological-osao-paulo., 49(4): 31-36.

Fries, C.R. (1984): Protein haemolymph factors and their role in invertebrate mechanisms: a review. In 'comparative pathology' (Editted by I.C. Chang) 6: 49-109. Plenum press, London. 
Gehad, M.A and Shaurub, E.H. (1997): Effect of two radiomodifiers on protein pattern of gamma irradiated blow fly, Chrysomia albiceps (WIED). J. Egypt Ger. Soc. Zool., 22: 105-116.

Gotz, P. and Boman, H.G. (1985): Insect immunity. In comprehensive insect physiology, biochemistry and pharmacology (Kurkut, G.A. and gilbert, L.I., Eds.), PP. 453-485. Pergamon press, Oxoford.

Graczyk, T.K.; Knight, R. and Tamang, L. (2005): Mechanical transmission of human protozoan parasites by insects. Cl. Microbiol. Rev. 18,128-132.

Harborne, J.B. (1984): Phytochemical Methods, $2^{\text {nd }}$ ed., pp (150-160). Edited by Chapman \&Hall. London New York.

Hightower, L.E. (1991): Heat shock, stress proteins, chaperones, and proteotoxicity, Cell 66: 191-197.

Ismail, I.E. and Fouad, M.A. (1985): Effect of a juvenile hormone analogue on the total carbohydrates, proteins and lipids of Pupae of Chrysomia albiceps (wiedman). J. of the Egyptian Society of Parastiol., 15(2): 645-649.

Khalaf, A.A. (1998): Biochemical and physiological impacts of two volatile plants oils on Muscina stabulans (Diptera: Muscidae). J. Egypt. Ger. Soc. Zool. V. 27, PP. 315-329.

Khalaf, A.A. and Hussein, K.T. (1997): Biocidal activity of selected volatile oils of plant origin against Muscina stabulans (Diptera-Muscidae), Ain Shams Sci. Bull., 35: 307-329.

Kinnear, J.F.; Martin, M.D.; and Thomson, J.A. (1971): Developmental changes in the late larvae of Calliphora stygia. III the occurrence and synthesis of specific tissue proteins. Aust.J. Biol. Sci., 24: 275-289.

Kyung, Y.H. and Kim, H.R. (1990): Characterization of haemolymph protein from Hyphantsia cunea Drwry. The Korean. J. Of Entoma., 24(4): 239-246.

Lindquist, S. (1986): The heat shock response, Annu. Rev. Biochem. (55): $1151-1191$.

Lowery, O.H.; Rosebrough, N.J.; Farr A.L. and Randoll, R.I. (1951): Protein measurement with the folin Phenol reagent. J. Biol. Chem., 193: 265-275.

Megahed, F.M. (1996): Effect of gamma radiation on the ultra- structure of ovaries and protein and esterase patterns of female Culex pipiens. Ph.D. Thesis, Fac. of Science, Cairo Univ. Egypt.

Mostafa, Z.K.; El-Sherif, L.S. and Hewady, M.A.A. (1995): Effect of certain volatile plant oils on the activity of malate dehydrogenase and malic enzyme in Pectinophora gossypiella (Saun.) and Earis insulana (Boisd) larvae (Lepidoptera: Noctuidae). J. Egypt Ger. Soc. Zool., 17: 13-23.

Nover, L. (1991): The Heat Shock Response, CRC Press, Boca Raton.

Oberlander, H.; Silhacek, D.L.; Leach, E.; Ishaaya, I. and Shaaya,E. (1998): Current status and future perspectives of the use of insect growth regulators for the control of stored product insects, J. Stored Prod. Res. 33: $1-6$.

Rajender, K. (1990): Effect of two different insecticides on the metabolism of nervous tissues of cockroach, Periplaneta americana. J. Envi. Biol., II: 3543.

Ratcliffe, N.A. (1985): Invertebrate immunity a promer for the non specialist immune. Lett., 10: 253-270.

Sabry, H.M. (2004): The use of some biological control agents against a myiasis producing fly. M. Sc. Thesis, Fac. Sci., Zagazig Univ. Egypt. 
Shoukry, I.F. et al.

Sanders, B.M. (1993): Stress proteins in aquatic organisms: an environmental perspective, Crit. Rev. Toxicol. 23: 49-75.

Schloter, H. (1985): Occurrence of weight gain and reduction inhibition of metamorphosis and storage protein formation in last larval instars of the Mexican bean beetle, Epilachna varivestis after injection of a zadirachtin. Entomol. Exp. Appl., 39(21): 191-195.

Senthil, N.S.; Chung, P.G., Murugan, K.(2004): Effect of botanicals and bacterial toxin on the gut enzyme of Cnaphalocrocis medinalis. Phytoparasitica 32, 433-443.

Senthil N.S.; Chung, P.G. and Murugan, K. (2005): Effect of biopesticides applied separately or together on nutritional indices of the rice leaf folder Cnaphalocrocis medinalis (Guene'e) (Lepidoptera: Pyralidae). Phytoparasitica 33, 187-195.

Shakoori, A.R. and Saleem, M.A. (1991): Coparative biochemical composition of a susceptible (FSSII) and two malathion resistant (CTC 12 and Pakistan) strains of Tribolium castaneum (Coleoptera: Tenebrionidae) Pakistan, J. Zool., 23: 1-16.

Shoukry, I.F. and Hussein, K.T. (1998): Toxicity and biochemical effects of two plant oils on the larvae of the greater wax moth, Galleria mellonella $L$. (Pyralidae-Lepidoptera). J. Egypt. Ger. Soc. Zool., 27: 99-116.

Shoukry, I.F.; Khalaf, A.A.; Hussein, K.T. and Khater, K.S. (2003): Toxicological evaluation of some botanical oils on biochemical aspects in the Indian meal moth, Plodia interpunctella HB. (Lepidoptera: Pyralidae). Egypt. J. Biol., 5: 155-163.

Sulaiman, S.; Sohadi, A.R.; Yurms, H. and Ibrahim, R. (1988): The role of some cyclorrhaphan flies as carriers of human helminths in Malaysia. Med. Vet. Entomol. 2, 1-6.

Tiwari, S. and Singh A. (2003): Control of common freshwater predatory fish, Channa punctatus, through Nerium indicum leaf extracts. Chemosphere $53,865-875$.

Wigglesworth, V.B. (1959): Insect blood cells. Ann. Rev. Entomol., 4: 1-16

Wilkinson, C.F. (1976): Insecticide Biochemistry and physiology.Plenum press, New York, U.S.A.

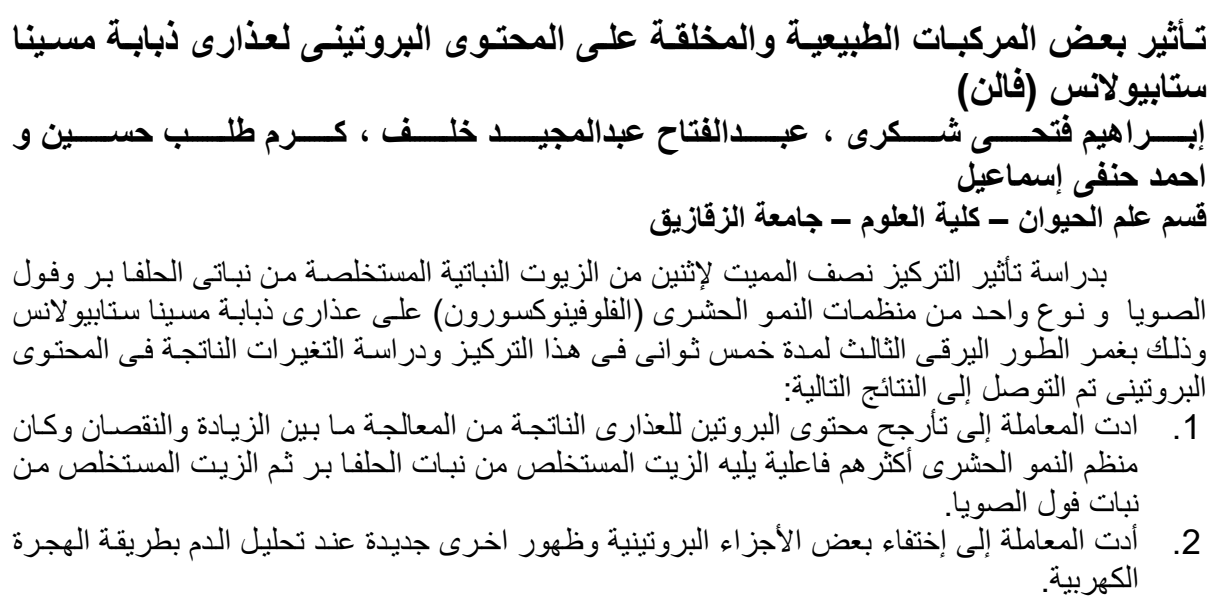

